\title{
Experimental Study of the Leading Motives in Learning a Foreign Language
}

\section{Maria Arkhipova}

Candidate of Psychological Sciences, Senior Teacher of the Department of Foreign Languages and Cultural Linguistics of the Institute of International Relations and World History, Nizhny Novgorod State University named after N.I. Lobachevsky

\section{Natalia Shutova}

Doctor of Psychological Sciences, Professor of the Department of Classical and Practical Psychology of the Faculty of Psychology and Pedagogics, Nizhny Novgorod State Pedagogical University named after Kozma Minin (Mininsky University

\section{Ekaterina Belova}

Candidate of Philological Sciences, Associate Professor, Head of the Department of Theory and Practice of Foreign Languages and Linguistic Didactics of the Faculty of Humanities, Nizhny Novgorod State Pedagogical University named after Kozma Minin (Mininsky University

\section{Olga Kim}

Senior Teacher of the Department of Foreign Professional Communication of the Faculty of Humanities Nizhny Novgorod State Pedagogical University named after Kozma Minin (Mininsky University).

\section{Olga Orlova}

\begin{abstract}
Candidate of Philological Sciences, Associate Professor, Head of the Department of Foreign Professional Communication of the Faculty of Humanities, Nizhny Novgorod State Pedagogical University named after Kozma Minin (Mininsky University)
\end{abstract}

\section{Doi:10.5901/mjss.2015.v6n6s5p115}

\section{Abstract}

The paper deals with studying the problem of motivation in foreign language learning. This work is performed within the general topic of scientific research on building a concept for improving students' motivation in learning a foreign language by means of musical influence. Development of this concept provides for the experimental study and clarification of leading motives for learning a foreign language. In our paper we discuss the particularities of foreign language as an academic discipline and students' psycho-physiological particularities reducing their motivation. The results of the experiment show that the interest of students to learning a foreign language is episodic in nature. The leading kind of motivation is the coercion motive i.e. seeking to avoid troubles and criticism. Initially set up to failure, the students feel insecure and anxious. We assume that the musical art included into learning activities in a natural manner promotes the creation of positive emotions, development of interest in studying the subject and thus improves the quality of education. Adjustment of emotional state of the educational activities subject using music contributes to optimization of learning activities. So, we see the prospect of our further research in selecting pieces of music and studying their impact on the subject of academic activities as psychological tools for creating emotional comfort, developing the interest in the study of the subject and, as a consequence, increasing the efficiency of the educational process.

Keywords: education, foreign language, motivation, leading motives.

\section{Introduction}

Currently, education in Russia is aimed at the development of children's intellectual and personal resources which promote self-development and efficient self-implementation in the future. Today the central task of the school is to support the development the learning, cognitive, creative motivation in students that provides them with an understanding of the value of personal activity, focusing on the implementation, and optimization of intellectual forces and efforts on the process and result of activity.

More than other activities the learning relies on the positive attitude of the student to acquisition of knowledge to 
finding the ways of getting them. Many Russian and foreign scientists (M.V. Arkhipova, 2013; N.V. Shutova, 2013; , V.G. Aseev, 1986; A. Jones, 1979; J. Kesler, 1973 et. al.) note that the today's adolescents have an ambiguous attitude to foreign language as a school subject, insufficient motivation in learning it. "Certainly it gives rise to a contradiction between the increasing demands of society, when a good language skills increase the competitiveness of specialist in any field and the traditional system of learning a foreign language in most Russian schools where the reproductive nature of learning is dominant. We believe that one of the causes of this phenomenon is insufficient level of theoretical and experimental development of the problem of motivation development in foreign language learning, consequently the arrangement of psycho-pedagogical conditions in educational institutions does not meet the educational needs." (M.V. Arkhipova, N.V. Shutova, 2013, 68).

In the view of a number of authors the motivation occupies a central place in the personality structure, is one of the main concepts used to explain the driving forces of the behaviour and activities (J.W. Atkinson, 1964; S.P. Grossman, 1979; A. Bolte, 2003; J. Kuhl, 2003; D.G. Moore, 2003; K. Burland, 2003; J.W. Davidson, 2003, et. al.).

The analysis of the features of the development of the learning motivation in adolescents is of great importance to us. The choice of this age group is associated with the fact that the adolescence is one of the most difficult periods for the personality development. Various aspects of study and development of motivation in learning of students are presented in numerous works (S.C.Moore, 2002; M. Oaksford, 2002; M. Zembylas, 2003, etc.), which differ in their approaches to the problem of motivation and motive of learning activity.

Modern age-related and pedagogical psychology of language teaching have a number of research papers dealing with various aspects of the development of learning motivation of the students: kinds of motives of academic activity -V.G. Aseev, 1976; V.G. Leontiev, 1987, et.al.; emotional mood at academic activity -V.G. Aseev, 1976; D.G. Moore, 2003; M. Zembylas, 2003, et.al.; interest as a kind of inner motivation of the student -V.G. Leontiev 1987; L.S. Vygotskij, 1956, et.al.

Studying the problem of motivation in academic activity, the authors distinguish two types of motivation - external and internal motivation. However, some authors while not denying the existence of the internal motivation, assign the leading role to the external motivation. The best motivation is the one in which a prominent place is occupied by social, socially significant motives, and then the motives associated with cognitive interests of students. Other authors believe that the best motivation is the predominance of inner motivation. Some works provide confirmation of the same importance of both kinds of motivation.

In our opinion the studies of R. Gardner and B. Lambert are interesting, they distinguish such types of motivation as an instrumental and integrative. So, the external needs, the need, coming from outside, reflect the instrumental motivation. The efficient learning of foreign languages requires integrative motivation that reflects the internal needs of the student (R.C. Gardner, W.E. Lambert, 1972).

When studying the motives of mastering a foreign language you should judge from the specific character of the foreign language as a school subject. So, following I.A. Zimnyaya we shall turn our attention to the analysis of three main features of foreign language as a learning subject: objectlessness, endlessness and heterogeneity. A significant specific feature of a foreign language as a school subject in comparison to other subjects is that mastering of language does not give a person the immediate knowledge of reality. In general, language, and specifically a foreign language, is a means of creating and then a form the existence and expression of idea of objective reality. In this context the language as the learning subject is objectless. It is only a media. Foreign language has no separate topic sections, like other subjects. When studying a foreign language it is impossible to know only vocabulary, not knowing grammar. You should know all the grammar, the entire vocabulary required for the communication conditions. In this context the language as a learning subject is endless. Heterogeneity is also a significant feature of language. In the broad sense of the word language includes a number of other phenomena, such as speech activity (processes of speaking and understanding), language system (language defined by a dictionary and grammar), etc. (I.A. Zimnjaja, 1991). These features of foreign language as learning subject form negative, subjective attitude to it as to the very difficult subject.

Researchers of the problem of language learning motivation note its decreasing level from class to class. Curiously enough, before learning a foreign language and at the beginning the students' motivation is very high. They want to communicate in foreign language with their peers, like to recite poems and sing songs in foreign language. But as soon as studying begins, the attitude of the students changes. Many give up, because this process implies a long time for accumulation of basic knowledge, the stage of primitive content, overcoming of various difficulties that moves away the achievement of the dreamed goals. As a result the motivation is reduced, the counter activity disappears. Other scientists give the similar data. So, by the end of the first year, the students' interest in learning a foreign language at school falls off. This trend persists up to 9th year of study, only then the interest increases a little, some students realize the importance of this subject for the further education and obtaining a profession. 
Analysis of scientific literature and our own teaching experience shows that in adolescence age, that is associated with psychophysiological change, increasing personal insecurity, the learning motivation of students is significantly reduced, training and, in particular, a motivation in learning a foreign language. Detection of specific foreign language learning motives in adolescents based on the specially developed diagnostic programs provides for identification of efficient approaches of students training that facilitate the optimization of this process.

\section{Research Methods}

The goal of our experimental study is to identify the features in the development of the main motives of the foreign language learning in adolescents. The ascertaining experiment that took place in four stages within two months was conducted with an objective to identify the features in the development of the main motives of the foreign language learning in adolescents. Each stage took up equal amount of time.

The experimental study was carried out on the basis of secondary general education schools in the city of Nizhny Novgorod. Adolescent students of 6-7 years of study (120 people) participated in this experiment. The experimental study was carried in the secondary schools without enhanced education in English language. According to the Federal basic curriculum for educational institutions the English lessons occupy 315 hours, three hours per week in these schools, and is expected that the students achieve the CEFR level A2 (Pre-Intermediate), which provides for the further education at the senior stage in senior secondary school, in professional educational institutions and for the further self-education. The choice of age is related to the fact that this age period is one of the most difficult periods for personality development. "The analysis of research studies indicates that the cognitive motives are not dominant in the motive structure of the adolescent students, in the most adolescents they require external stimulation and are defined by instability, contextual nature, insufficient efficiency, insufficient generalized character, orientation to the results" (M.V.Arkhipova, 2012, 10). Theoretical and experimental studies on the problem of motivation of foreign language learning in recent years and our own experience showed that adolescence is the most critical age in terms of the fall of the motivation in foreign language learning (A. Jones, 1979; J.Kesler, 1973; N.V.Shutova, 2013; M.V.Arkhipova, 2012 et. al.).

\section{Results and Discussion}

At the first stage the experimental study was aimed at the detection of the leading motives of learning a foreign language. Let us refer to the obtained results.

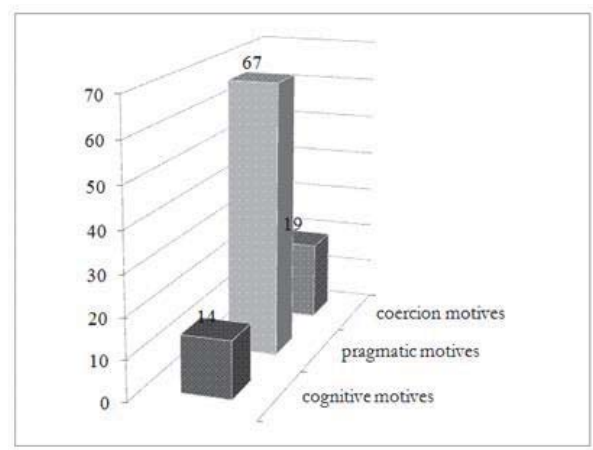

Figure 1. Motives of foreign language learning in adolescents

Analysis of experimental materials shows that only 14 percent of students have leading cognitive motives. These young people are focused on acquisition of deep and competent knowledge, feel the need to learn to work independently. This group of adolescents note that learning of English provides an opportunity to know a lot of new, interesting and important things, and show their abilities. The testees consider the knowledge of English essential and underline the need to obtain more knowledge on this subject. Pragmatic motives dominate in $67 \%$ of adolescents in the process of learning a foreign language. In opinion of the testees' the learning of foreign language is important because it gives an opportunity to get a prestigious job, appraisal of teachers and parents, stand out among the friends, get a good mark. But still, given this 
degree of realizing the importance of subject studied, more than half of adolescents note that arising difficulties cause negative attitude to the learning of the subject, make it less attractive. In $19 \%$ of young people during learning a foreign language the motive of coercion is leading, that is manifested in fear of punishment by adults for the bad progress. In our view, such an adverse factor as dominance of coercion motive often gives a negative connotation of learning activities that, without doubt, adversely affects the success of the training.

From the conversations with the adolescents we found that the main difficulties in learning a foreign language are connected with the study of theoretical issues. So, more than a third of students note that the topics related to the study of phonetic and some grammatical issues may be entirely excluded. Half of the surveyed adolescents admit that they carry out the tasks, given at lessons, and participate in the discussions only under the supervision of a teacher. The presence of the teacher and the possibility of negative consequences in case of failure to fulfill the exercise is the dominant factor when fulfilling the tasks.

At the second stage of the experimental study we studied the interest of adolescents in a positive result of their activities. The results are displayed in Figure 2.

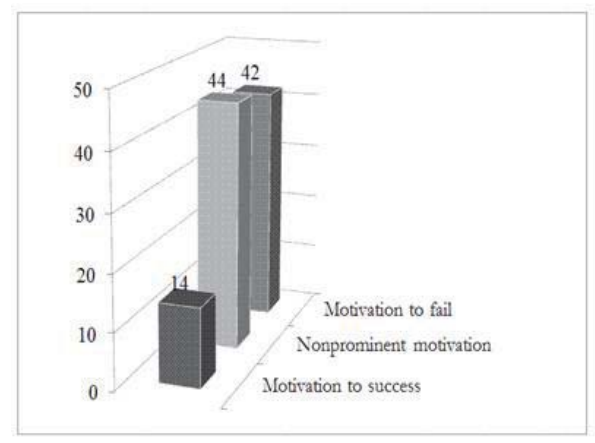

Figure 2. Motivation of adolescents for obtaining a positive result of their activities

It should be noted that only $14 \%$ of the testees are set up for the success in learning a foreign language. This group of adolescents when proceeding to the activity is focused on achieving a positive result. Hope for success and need for achieving success and ideas of positive expectations lie at the basis of their activity. Motivation to fail is typical for $42 \%$ of adolescents. Accordingly, when get started on the activity, they a priori are afraid of a possible failure, try to find a way to avoid a hypothetical failure. They do not think about the ways to achieve a positive result. in the conditions when it is necessary to perform complex tasks they can fall into the state of panic. It is necessary to notice the large number of adolescents (44\%) with non-prominent motivation to achieve success and avoid failure.

Interest is one of the main and most persistent motives when teaching the subject, providing a positive impact on the process of perception, thinking, memory, and on the result of academic activity. At the third stage of the experimental study we identified the interest of students in the tasks fulfilled in the process of learning a foreign language.

Our results show that the interest in educational tasks is present only in $29 \%$ of adolescents. These students are interested in the content of the subject as well as the forms of teacher's presentation of educational material and forms of working with it. $47 \%$ of adolescents note that only a certain facts are interesting in learning a foreign language. Episodic interest in the given tasks is registered in this group of adolescents. The most students have interest in some topics discussed at the lesson, new facts related to the culture, history, traditions and customs of the country or specific grammatical phenomena, forms of work with the group, educational material (films, presentations, singing). $24 \%$ of adolescents consider the educational tasks performed at the lessons to be boring. The proposed tasks are unattractive to these adolescents, and when possible they would prefer to exclude English language from the educational process. So, a third of adolescents remain indifferent to the foreign language learning, do not seek to obtain new knowledge and achieve positive results in this activity.

In our view, one of the reasons for the low interest of students to learning a foreign language is the difficulties with the language acquisition. The students treat the foreign language as one of the most difficult subjects, they have special difficulties with the grammar. Certainly, a lack of interest in foreign language affects the motivation of learning it, and as a consequence adversely affects the results. Thus, the lack of interest in the studied subject complicates the learning 
success.

At the third stage of the study we studied the emotional attitude of adolescents to the process of this activity. A summary of the results of the study of the emotional attitude of adolescents to the process and the result of activity are presented in Figure 3.

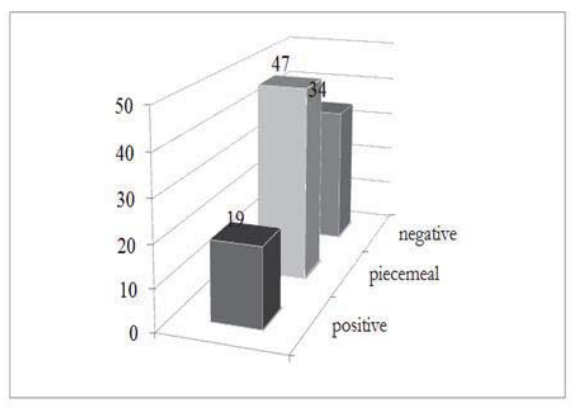

Figure 3. Emotional attitude of adolescents to the process of learning a foreign language

Based on the obtained results we can conclude that $19 \%$ of adolescents have positive emotional attitude to the process and the result of activity. They are interested in the exercises, are actively involved in their discussion, eager to continue their activity and to obtain best results. Positive emotional attitude of $47 \%$ of adolescents is piecemeal. This group of adolescents does not seek to continue learning on their own initiative, often remains indifferent at the foreign language lessons. Negative emotional attitude to the process and the result of activity is typical for $34 \%$ of students. They react negatively to everything that is related to the learning of a foreign language.

Thus, the positive emotional attitude to learning a foreign language is typical for the few adolescents. The most prominent reasons that negatively affect the students' attitude to the English language are the complex theoretical material, lack of interest in language learning by the classmates. From the interviews with adolescents, we've also found that their negative attitude to language learning is associated to the lack of interesting topics, performing the same type tasks.

The adolescents point out that at the English lessons it often happens that nobody wants to study it. In our view, this may be associated to the variety of reasons. Firstly, the state of nervous tension may contribute to this, when the students were unable to the get to the bottom of the issues being discussed. Thus, the counter activity disappears rapidly disappears, and as a result, the motivation of learning a foreign language is falling. Secondly, this may be related to activities carried out at the English lessons. During the conversation, we found that adolescents treat the English tasks uninteresting, and perform them only because it is required by the teacher.

At the final stage of the study we identified the features of emotional well-being of adolescents at the foreign language classes. The obtained results are presented in Figure 4.

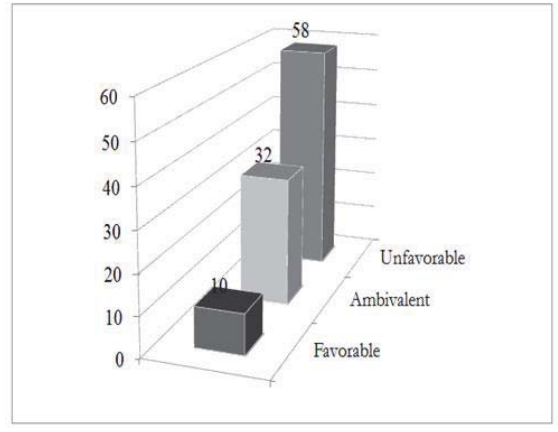

Figure 4. The results of self-assessment of the emotional state of the adolescents at the foreign language lessons 
The obtained data allowed noting that only $10 \%$ of adolescents have a favorable emotional state at the lessons. Emotional state of $32 \%$ of adolescents is estimated as ambivalent. $58 \%$ of testees tell about their emotional discomfort at the English lessons. The conversation with the adolescents revealed that more than half of them remain indifferent at the lessons, often feel nervous when answering, especially when they come to the blackboard, feeling nervous about the "ironic smiles of the classmates" and the "teacher comments". Of course, the negative emotional state of students in the process of the activity has a negative impact on motivation of foreign language learning, because the emotions perform the motivation function in any activity.

\section{Conclusion}

The results of the experiment show that the adolescents have manifested occasional interest in the subject and in the performed learning tasks that fades away as difficulties emerge and is achieved mostly due to extra-curricular activities. Most adolescents do not show interest in the study of a foreign language. They are indifferent to the process of the activity. The leading type of motive in adolescents during learning a foreign language is that of coercion - an endeavor to avoid troubles. This group of adolescents thinks that English could be completely excluded from the educational process and associate learning of it with the fear of punishment by adults. The learning activities carried out at the lessons are not interesting and complicated for the adolescents, they choose the simplest tasks and immediately stop to perform them when difficulties arise.

A study of motivation of foreign language learning by adolescents has allowed us to note that orientation to success in the activities is typical for $14 \%$ of adolescents. $44 \%$ of adolescents have non-prominent motivation to success or fail. The remaining testees in the process of learning a foreign language think not about ways to success, but about ways of avoiding hypothetical failure. Set up to fail from the beginning, these adolescents are anxious and low confident in their abilities.

The lack of interest is a factor that adversely affects any activity, including learning activity. Consequently, the lack of interest in foreign language learning in the students has a negative impact on the process and result of learning activity. A third of the students have a negative emotional attitude to the process and the to result of the activities, and more than half feel emotional discomfort in the process of learning a foreign language. Adolescents are sensitive about any criticism, although they not always strongly react to it, they prefer not to express their point of view at the lesson being unsure about the correctness of his judgment. Their positive attitude to the process and the result of the activities is piecewise, emotional well-being is estimated as ambivalent. Adolescents are aware of the importance of learning a foreign language in the modern world, but most of them have negative emotions during the studying of the subject.

Based on the results of this stage of study we have come to the conclusion that most adolescents have a relatively low level of development of motivation for a foreign language learning. Overcoming the identified negative trends has required the development of theoretical, organizational and technological and content-related basis of the experimental program, aimed at the development of motivation in foreign language learning. In connection with this, it is relevant and necessary to look for efficient means and methods of teaching foreign language that satisfy physiological and psychological needs of today's students and enhance motivation in learning a foreign language. We assume that special musical influence included in the process of foreign language learning activity can have a positive impact on the emotional attitude to both process and result of activity and enhance the interest in the subject studied. Therefore, the aim of our further research is selection of musical compositions and studying their effect on the subject of learning activity as that of psychological tools for creating emotional comfort, development of interest in learning of the subject and, as a consequence, for enhancing the efficiency of the learning process.

\section{References}

Arkhipova, M.V., Shutova, N.V. (2013). Psihologicheskie vozmozhnosti ispol'zovanija muzykal'nogo iskusstva v processe izuchenija inostrannogo jazyka shkol'nikami [Psychological opportunities of using music with pupils in the process of learning a foreign language]. Historical and social-educational idea, Volume No. 1 (17), 68-72.

Arkhipova, M.V. (2012). Razvitie motivacii izuchenija inostrannogo jazyka u podrostkov sredstvami muzykal'nogo iskusstva [Developing adolescents' motivation to learn foreign languages by means of music]. Author's abstract of a Ph.d. thesis. Izdatel'stvo Nizhniy Novgorod.

Aseev ,V.G. (1976). Motivacija povedenija i formirovanie lichnosti [Bahaviour motivation and personality development]. Moskva: Izdatel'stvo Mysl '.

Atkinson, J.W. (1964). An Introduction to Motivation. N. Y, Toronto.

Bolte A., Goschke T., Kuhl J. (2003). The Emotion and Intuition: Effects of Positive and Negative Mood on Implicit Judgments of 
Semantic Coherence. Psychological Science, Vol. 14, 416-422.

Gardner, R.C., Lambert, W.E. (1972). Attitudes and motivation in second language learning. Rowley, MA: Newbury House. Grossman, S.P. (1979). The Biology of Motivation. Annual review of Psychology, Vol.30, 209-242.

Jones, A. (1979). Counseling Adolescent: School and After. Personal Service in secondary education. Great Britain (London). Kesler, J. (1973). Let us Succeed with our Adolescents. David C. Cook Publishing Co, Elgin.

Leontiev, V.G. (1987). Psihologicheskie mehanizmy motivacii uchebnoj dejatel'nosti [Psychological mechanisms of learning motivation]. Novosibirsk: Izdatel'stvo NGPI.

Moore, D.G., Burland, K., Davidson, J.W. (2003). The Social Context of Musical Success: A developmental account. British Journal of Psychology, Vol. 94, p. 529-550

Moore, S.C., Oaksford, M. (2002). Some Long-term Effects of Emotion on Cognition. - British Journal of Psychology, Vol. 93, 383-395

Vygotskij, L.S. (1956). Izbrannye psihologicheskie issledovanija [Selected psychological research]. Moskva: Izdatel'stvo APN RSFSR.

Zembylas, M. (2003). Emotions and Teacher Identity: a post structural perspective. Teachers and Teaching: Theory and Practice, Vol.9, 213-238.

Zimnjaja, I.A. (1991). Psihologija obuchenija inostrannym jazykam v shkole [Psychology of teaching foreign languages at school]. Moskva: Izdatel'stvo Prosveshchenie. 